American Journal of Pharmaceutical Education 2019; 83 (6) Article 7658.

\title{
AACP REPORT
}

\section{The Pharmacy Student Population: Applications Received 2017-18, Degrees Conferred 2017-18, Fall 2018 Enrollments}

\author{
Jamie N. Taylor, BA, Nancy T. Nguyen, MPP, Melissa A. Gray, BS \\ American Association of Colleges of Pharmacy, Arlington, Virginia
}

\section{INTRODUCTION}

This report presents data that describe the 2017-18 pharmacy application pool, degrees conferred in 2017-18, and fall 2018 pharmacy program enrollments. Data for this report were requested from 143 US colleges and schools of pharmacy recognized by the Accreditation Council for Pharmacy Education (ACPE) using five separate survey instruments.

There were previously two professional education programs at US colleges and schools of pharmacy: one leading to a baccalaureate in pharmacy, and the other leading to the Doctor of Pharmacy (PharmD) degree. However, June 30, 2005 marked the official expiration of the ACPE standards to the baccalaureate in pharmacy (BS Pharmacy) degree programs in accordance with the transition to the Doctor of Pharmacy (PharmD) degree as the sole professional degree program in the US Some colleges and schools of pharmacy conferred degrees in the BS Pharmacy program until 2004-05.

For the purpose of this report, students in Doctor of Pharmacy programs are categorized under PharmD1 when the program leads to a Doctor of Pharmacy degree conferred as the first professional degree. Students who have already received a baccalaureate in pharmacy and are enrolled in a Doctor of Pharmacy degree program are categorized under PharmD2.

The following definitions refer to the race/ethnicity groups as used in this report. White refers to US citizens or permanent residents having origins in any of the original peoples of Europe, the Middle East, or North Africa. Black or African American refers to US citizens or permanent residents having origins in any of the black racial groups of Africa. Hispanic or Latino refers to US citizens or permanent residents of Cuban, Mexican, Puerto Rican, South or Central American, or other Spanish culture or origin, regardless of race. Asian refers to US citizens or permanent residents having origins in any of the original peoples of the Far East, Southeast Asia, or the Indian Subcontinent, including, for example, Cambodia, China, India, Japan, Korea, Malaysia, Paki- stan, the Philippine Islands, Thailand, and Vietnam. $\mathrm{Na}$ tive Hawaiian or Other Pacific Islander refers to US citizens or permanent residents having origins in any of the original peoples of Hawaii, Guam, Samoa, or other Pacific Islands. Prior to 2011, these students were included in the Asian category. American Indian or Alaska Native refers to US citizens or permanent residents having origins in any of the original peoples of North and South America (including Central America) who maintains cultural identification through tribal affiliation or community attachment. Two or More Races refers to US citizens or permanent residents who are not Hispanic or Latino and identify themselves by more than one race. Unknown refers to US citizens or permanent residents whose race and ethnicity are not known. Prior to 2011, this category was labeled Other/Unknown and students that were of two or more races were included in this category. Finally, International/Foreign refers to citizens of a foreign country/permanent residents of a country other than the US.

\section{7-2018 APPLICATION POOL}

The 2017-18 Application Pool Survey was conducted online in October 2018 with an announcement and request for participation sent to the survey coordinator at each of the 143 colleges and schools of pharmacy in the US recognized by ACPE. After follow-up correspondence, 143 colleges and schools (100\%) submitted the requested information. Included in the application pool are applicants who applied for admission and submitted all required application materials as defined by the Pharmacy College Application Service (PharmCAS) between September 2017 and August 2018 for the entering class of fall 2018. Numbers reported represent the number of applications, not applicants, and may represent multiple applications submitted by individual applicants.

During the period September 2017 through August 2018 the reporting institutions received 60,042 applications for admission. 
American Journal of Pharmaceutical Education 2019; 83 (6) Article 7658.

Table 1. Distribution of 2017-18 Applications by Gender and Race/Ethnicity of Applicant ${ }^{\mathrm{a}}$

\begin{tabular}{lcccc}
\hline Race/Ethnicity & Male & Female & $\begin{array}{c}\text { Gender } \\
\text { Not Specified }\end{array}$ & Total (\%) \\
\hline White $^{\text {b }}$ & 8,563 & 13,692 & 26 & $22,281(37.1)$ \\
Black or African American $^{\text {b }}$ & 3,014 & 4,529 & 5 & $7,548(12.6)$ \\
Hispanic or Latino $^{\text {b }}$ & 2,001 & 2,900 & 8 & $4,909(8.2)$ \\
Asian $^{\text {b }}$ & 6,786 & 10,450 & 16 & $17,252(28.7)$ \\
Native Hawaiian or Other Pacific Islander $^{\mathrm{b}}$ & 22 & 40 & 0 & $62(0.1)$ \\
American Indian or Alaska Native $^{\mathrm{b}}$ & 36 & 115 & 1 & $152(0.3)$ \\
Two or more races $^{\mathrm{b}}$ & 728 & 1,148 & 13 & $1,889(3.1)$ \\
Unknown $^{\mathrm{b}}$ & 979 & 1,913 & 52 & $2,944(4.9)$ \\
International/Foreign $^{\mathrm{c}}$ & 1,061 & 1,942 & 2 & $3,005(5.0)$ \\
& & & & 60,042 \\
Total & 23,190 & 36,729 & 123 & \\
\hline
\end{tabular}

${ }^{\mathrm{a}}$ Represents data submitted by 143 schools

${ }^{\mathrm{b}}$ US citizen or permanent resident

${ }^{\mathrm{c}}$ Citizens of a foreign country/permanent residents of a country other than the US

In $2017-18$, females submitted $61.2 \%$ of the applications to pharmacy colleges and schools; males submitted $38.6 \%$; gender unknown/not reported submitted $0.2 \%$. White Americans submitted $37.1 \%$ of the applications, Asian Americans submitted $28.7 \%$ of the applications, and underrepresented minorities submitted $21.1 \%$ of the applications (Black or African American, 12.6\%; Hispanic or Latino, 8.2\%; Native Hawaiian or Other Pacific Islander, $0.1 \%$; American Indian or Alaska Native, $0.3 \%$ ). Applications submitted from students that identified as two or more races totaled $3.1 \%$ and $5.0 \%$ of the applications were submitted by foreign, nonpermanent residents [Table 1]. For the first time in fourteen years, colleges and schools of pharmacy received slightly more applications from in-state residents (50.4\%) compared to $49.6 \%$ from out-of-state residents.

Over $75 \%(75.1 \%)$ of the applications to colleges and schools of pharmacy were submitted by individuals who had 3 or more years of postsecondary experience (3 or more years of college/no degree, $33.2 \%$; baccalau- reate, $39.3 \%$; master's, $2.2 \%$; doctoral degree, $0.5 \%$ ), [Table 2].

\section{7-2018 DEGREES CONFERRED}

The 2017-18 Undergraduate and Professional Pharmacy Degrees Conferred and Graduate Pharmacy Degrees Conferred surveys were conducted online in October 2018, with an announcement and request for participation sent to the survey coordinator at each of the 143 colleges and schools of pharmacy in the US recognized by ACPE. Submission of the data was requested by December 2018. After follow-up correspondence, 143 colleges and schools (100\%) submitted the Undergraduate and Professional Degrees Conferred Survey and the Graduate Degrees Conferred Survey.

\section{Professional Degrees Conferred}

Numbers of degrees conferred by US colleges and schools of pharmacy from 1965 to 2018 are presented in Table 3.

Table 2. Distribution of 2017-18 Applications to First Professional Degree Programs by Gender and Previous Postsecondary Experience of Applicant ${ }^{\mathrm{a}}$

\begin{tabular}{|c|c|c|c|c|}
\hline Postsecondary Experience & Male & Female & $\begin{array}{c}\text { Gender Not } \\
\text { Specified }\end{array}$ & Total (\%) \\
\hline 0 Years of College & 2,587 & 4,695 & 17 & $7,299(12.2)$ \\
\hline Associate degree & 1,718 & 2,795 & 13 & $4,526(7.5)$ \\
\hline 3 or More Years of College/No Degree & 7,522 & 12,366 & 22 & $19,910(33.2)$ \\
\hline Baccalaureate Degree & 9,460 & 13,981 & 145 & $23,586(39.3)$ \\
\hline Doctoral Degree & 185 & 110 & 0 & $295(0.5)$ \\
\hline
\end{tabular}

${ }^{a}$ Represents data submitted by 143 schools 


\section{American Journal of Pharmaceutical Education 2019; 83 (6) Article 7658.}

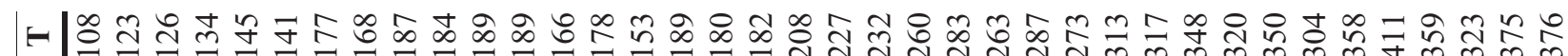

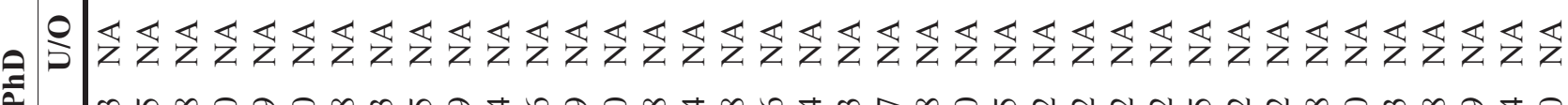

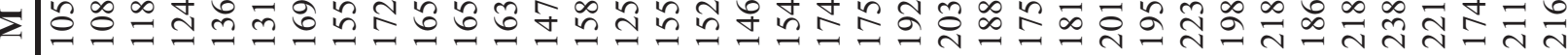

-

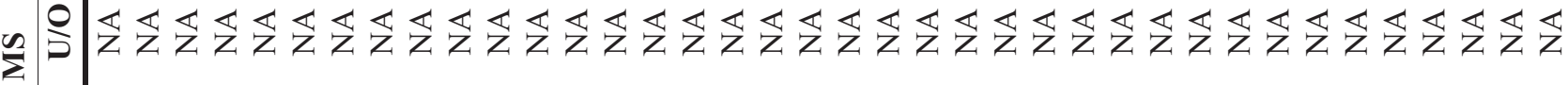

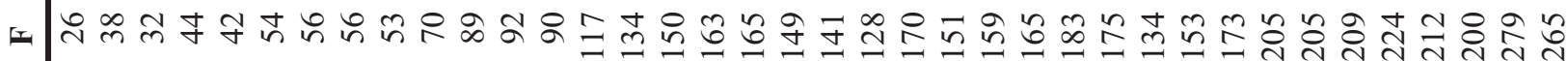

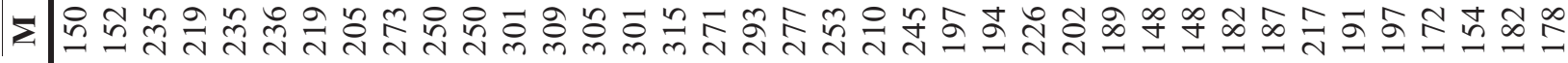

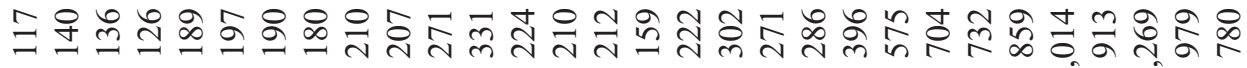

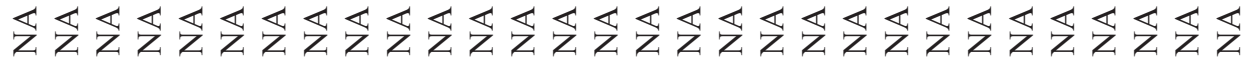

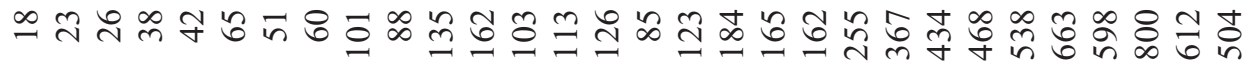

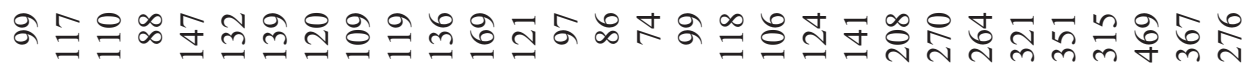

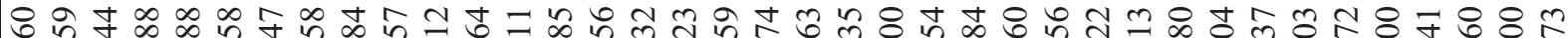

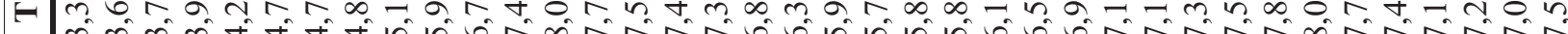

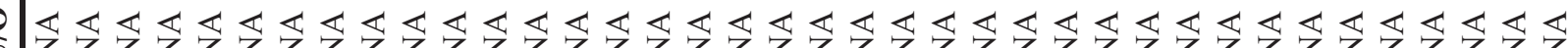

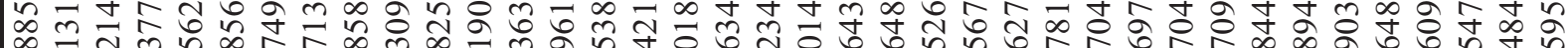

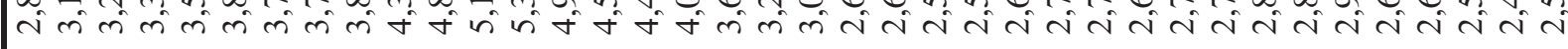

ભ

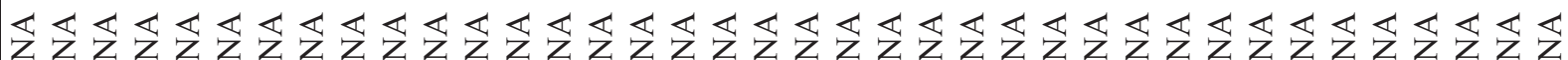

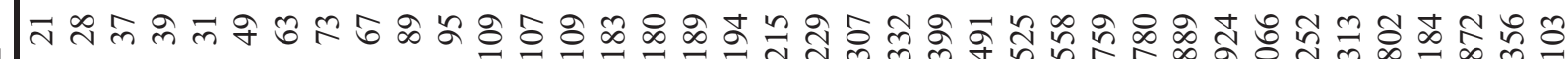

니유

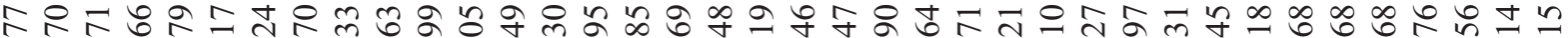

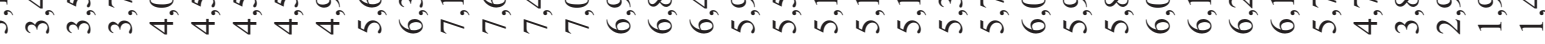

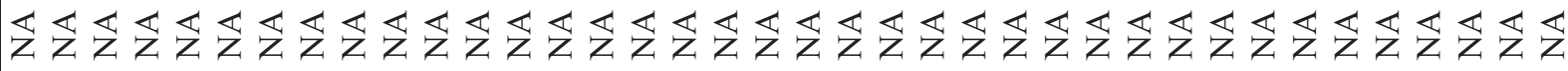
苍8

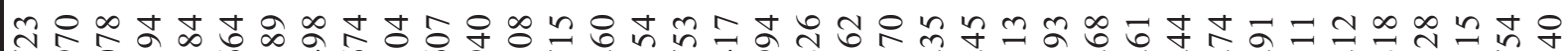


American Journal of Pharmaceutical Education 2019; 83 (6) Article 7658.

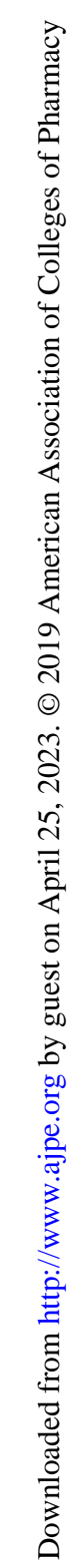

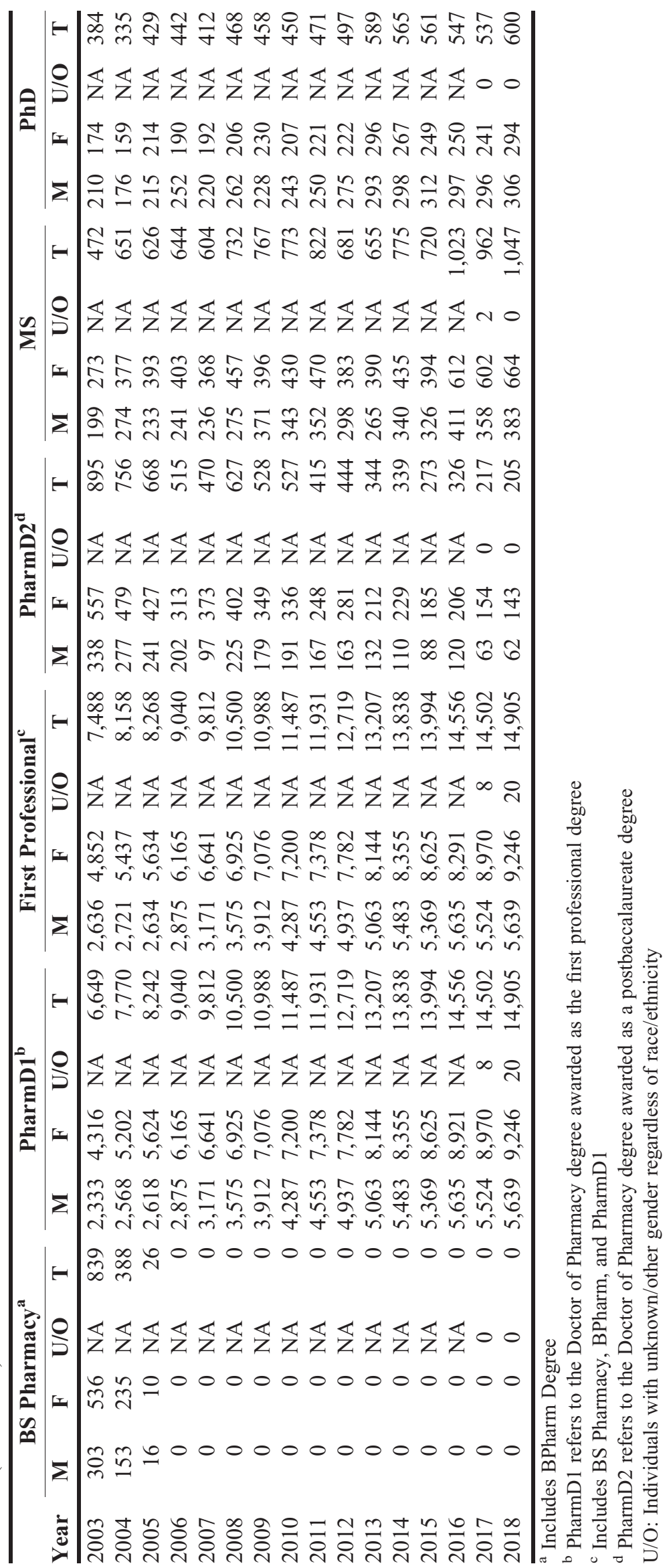




\section{American Journal of Pharmaceutical Education 2019; 83 (6) Article 7658.}

\section{First Professional Degrees Conferred}

In 2017-18, 135 colleges and schools of pharmacy reported conferring the Doctor of Pharmacy as a first professional degree (PharmD1). Graduating PharmD1 class sizes ranged from 29 students to 316 students (median, 95 students). Eight of the 143 colleges and schools did not confer degrees in 2017-18. These schools were new programs whose students had not yet progressed through the entire curriculum (Marshall B. Ketchum, Larkin, William Carey, Binghamton, High Point, Texas at El Paso, Texas at Tyler, and Medical College of WI).

In 2017-18 there were 14,905 first professional degrees conferred by colleges and schools compared to 14,502 in 2016-17 [Table 4]. The total number of first professional degrees conferred in 2017-18 represented a $2.8 \%$ increase from the total number of first professional degrees conferred in 2016-17 [Table 5].

In $1979-80$, men received $59.5 \%$ of the first professional degrees conferred by colleges and schools and women received $40.5 \%$. Over the past 35 years, these percentages have shifted dramatically and, in 2017-18, men received $37.8 \%$ of the first professional degrees conferred and $62.0 \%$ of these degrees were received by women. Women received the highest percentage of degrees conferred in 2005-06 (68.2\%) [Table 6].

White Americans received $50.6 \%$ of first professional degrees conferred in 2017-18. Asian Americans received $25.8 \%$ of the first professional degrees. Underrepresented minorities received $14.1 \%$ of the first professional degrees conferred in 2017-18 (Black or African American, 8.3\%; Hispanic or Latino, 5.4\%; Native Hawaiian or Other Pacific Islander, $0.2 \%$; American Indian or Alaska Native, $0.2 \%$ ). The percentage of first professional degree recipients who were of two or more races was $2.4 \%$ and the percentage of recipients who were foreign, nonpermanent residents of the US was $2.7 \%$ [Table 7].

\section{Doctor of Pharmacy Degrees Conferred to Post Baccalaureate Students}

Six colleges and schools conferred the PharmD degree to post baccalaureate students in 2017-18. The number of graduates per institution ranged from 6 to 73 students (median, 34.5 students). The number of Doctor of Pharmacy degrees conferred as postbaccalaureate degrees (PharmD2) decreased by $5.5 \%$ to 205 in 2017-18 from 217 in 2016-17 [Table 5]. More women than men received PharmD2 degrees in 2017-18 (women, 69.8\%; men, 30.2\%) [Table 6].

White Americans received $24.9 \%$ of PharmD2 degrees conferred in 2017-18. Asian Americans received
Table 4. Baccalaureate and Doctor of Pharmacy (PharmD1) Degrees as \%ages of Total First Professional Degrees Conferred 1981-2018

\begin{tabular}{|c|c|c|c|}
\hline Year & $\begin{array}{c}\text { BS Pharmacy } \\
\text { n }(\%)\end{array}$ & $\begin{array}{c}\text { PharmD1 }^{\text {b }} \\
\text { n }(\%)\end{array}$ & $\begin{array}{c}\text { First Professional }^{\mathrm{c}} \\
\text { n }\end{array}$ \\
\hline 1981 & $6,869(93.8)$ & $454(6.2)$ & 7,323 \\
\hline 1982 & $6,448(94.0)$ & $411(6.0)$ & 6,859 \\
\hline 1983 & $5,919(92.9)$ & $455(7.1)$ & 6,374 \\
\hline 1984 & $5,546(93.0)$ & $417(7.0)$ & 5,963 \\
\hline 1985 & $5,147(89.7)$ & $588(10.3)$ & 5,735 \\
\hline 1986 & $5,190(89.5)$ & $610(10.5)$ & 5,800 \\
\hline 1987 & $5,164(88.2)$ & $690(11.8)$ & 5,854 \\
\hline 1988 & $5,371(86.9)$ & $813(13.1)$ & 6,184 \\
\hline 1989 & $5,721(87.3)$ & 839 (12.7) & 6,560 \\
\hline 1990 & $6,010(86.4)$ & $946(13.6)$ & 6,956 \\
\hline 1991 & $5,927(83.2)$ & $1,195(16.8)$ & 7,122 \\
\hline 1992 & $5,897(82.9)$ & $1,216(17.1)$ & 7,113 \\
\hline 1993 & $6,031(81.7)$ & $1,349(18.3)$ & 7,380 \\
\hline 1994 & $6,145(81.9)$ & $1,359(18.1)$ & 7,504 \\
\hline 1995 & $6,218(79.3)$ & $1,619(20.7)$ & 7,837 \\
\hline 1996 & $6,168(77.1)$ & $1,835(22.9)$ & 8,003 \\
\hline 1997 & $5,768(74.2)$ & $2,004(25.8)$ & 7,772 \\
\hline 1998 & $4,768(64.4)$ & $2,632(35.6)$ & 7,400 \\
\hline 1999 & $3,876(54.3)$ & $3,265(45.7)$ & 7,141 \\
\hline 2000 & $2,956(40.7)$ & $4,304(59.3)$ & 7,260 \\
\hline 2001 & $1,914(27.3)$ & $5,086(72.7)$ & 7,000 \\
\hline 2002 & $1,415(18.7)$ & $6,158(81.3)$ & 7,573 \\
\hline 2003 & 839 (11.2) & $6,649(88.8)$ & 7,488 \\
\hline 2004 & $388(4.8)$ & $7,770(95.2)$ & 8,158 \\
\hline 2005 & $26(0.3)$ & 8,242 (99.7) & 8,268 \\
\hline 2006 & $0(0.0)$ & $9,040(100.0)$ & 9,040 \\
\hline 2007 & $0(0.0)$ & $9,812(100.0)$ & 9,812 \\
\hline 2008 & $0(0.0)$ & $10,500(100.0)$ & 10,500 \\
\hline 2009 & $0(0.0)$ & $10,988(100.0)$ & 10,988 \\
\hline 2010 & $0(0.0)$ & $11,487(100.0)$ & 11,487 \\
\hline 2011 & $0(0.0)$ & $11,931(100.0)$ & 11,931 \\
\hline 2012 & $0(0.0)$ & $12,719(100.0)$ & 12,719 \\
\hline 2013 & $0(0.0)$ & $13,207(100.0)$ & 13,207 \\
\hline 2014 & $0(0.0)$ & $13,838(100.0)$ & 13,838 \\
\hline 2015 & $0(0.0)$ & $13,994(100.0)$ & 13,994 \\
\hline 2016 & $0(0.0)$ & $14,556(100.0)$ & 14,556 \\
\hline 2017 & $0(0.0)$ & $14,502(100.0)$ & 14,502 \\
\hline 2018 & $0(0.0)$ & $14,905(100.0)$ & 14,905 \\
\hline
\end{tabular}

${ }^{a}$ Includes BPharm degree

${ }^{b}$ PharmD1 refers to the Doctor of Pharmacy degree awarded as the first professional degree

${ }^{\mathrm{c}}$ Includes BS Pharmacy, BPharm, and PharmD1

$22.0 \%$ of the PharmD2 degrees conferred. Underrepresented minorities received $16.1 \%$ of the PharmD2 degrees conferred (Black or African American, 13.7\%; Hispanic or Latino, 2.0\%; Native Hawaiian or Other Pacific Islander, 0.0\%; American Indian or Alaska Native, 0.5\%). Students of two or more races received 1.0 of PharmD2 
American Journal of Pharmaceutical Education 2019; 83 (6) Article 7658.

Table 5. Annual \%age Change in Number of Pharmacy Degrees Conferred 1981-2018 Over Previous Year

\begin{tabular}{|c|c|c|c|c|}
\hline Year & $\frac{\text { First Professional }^{\mathrm{a}}}{\text { No. (\% Change) }}$ & $\frac{\text { PharmD2 }^{\mathrm{b}}}{\text { No. }(\% \text { Change })}$ & $\frac{\text { MS }}{\text { No. (\% Change) }}$ & $\frac{\text { PhD }}{\text { No. }(\% \text { Change })}$ \\
\hline 1981 & $7,323(-1.5)$ & $210(+16.7)$ & $434(-6.7)$ & $180(-4.8)$ \\
\hline 1982 & $6,859(-6.3)$ & $207(-1.4)$ & $458(+5.5)$ & $182(+1.1)$ \\
\hline 1983 & $6,374(-7.1)$ & $271(+30.9)$ & $426(-7.0)$ & $208(+14.3)$ \\
\hline 1984 & $5,963(-6.4)$ & $331(+22.2)$ & $394(-7.5)$ & $227(+9.1)$ \\
\hline 1985 & $5,735(-3.8)$ & $224(-32.3)$ & $338(-14.2)$ & $232(+2.2)$ \\
\hline 1986 & $5,800(+1.1)$ & $210(-6.3)$ & $415(+22.8)$ & $260(+12.1)$ \\
\hline 1987 & $5,854(+0.9)$ & $212(+1.0)$ & $348(-16.1)$ & $283(+8.8)$ \\
\hline 1988 & $6,184(+5.6)$ & $159(-25.0)$ & $353(+1.4)$ & $263(-7.1)$ \\
\hline 1989 & $6,560(+6.0)$ & $222(+39.6)$ & $391(+10.8)$ & $287(+9.1)$ \\
\hline 1990 & $6,956(+6.0)$ & $302(+36.0)$ & $385(-1.5)$ & $273(-4.9)$ \\
\hline 1991 & $7,122(+2.4)$ & $271(-10.3)$ & $364(-5.5)$ & $313(+14.7)$ \\
\hline 1992 & $7,113(-0.1)$ & $286(+5.5)$ & $282(-22.5)$ & $317(+1.3)$ \\
\hline 1993 & $7,380(+3.8)$ & $396(+38.5)$ & $301(+6.7)$ & $348(+9.8)$ \\
\hline 1994 & $7,504(+1.7)$ & $575(+45.2)$ & $355(+17.9)$ & $320(-8.0)$ \\
\hline 1995 & $7,837(+4.4)$ & $704(+22.4)$ & $392(+10.4)$ & $350(+9.4)$ \\
\hline 1996 & $8,003(+2.1)$ & $732(+4.0)$ & $422(+7.7)$ & $304(-13.1)$ \\
\hline 1997 & $7,772(-2.9)$ & $859(+17.3)$ & $400(-5.2)$ & $358(+17.8)$ \\
\hline 1998 & $7,400(-4.8)$ & $1,014(+18.0)$ & $421(+5.3)$ & $411(+14.8)$ \\
\hline 1999 & $7,141(-3.5)$ & $913(-10.0)$ & $384(-8.8)$ & $359(-12.7)$ \\
\hline 2000 & $7,260(+1.7)$ & $1,269(+39.0)$ & $354(-7.8)$ & $323(-10.0)$ \\
\hline 2001 & $7,000(-3.6)$ & $979(-22.9)$ & $461(+30.2)$ & $375(+16.1)$ \\
\hline 2002 & $7,573(+8.2)$ & $780(-20.3)$ & $443(-3.9)$ & $376(+0)$ \\
\hline 2003 & $7,488(-1.1)$ & $895(+14.7)$ & $472(+6.5)$ & $384(+2.1)$ \\
\hline 2004 & $8,158(+8.9)$ & $756(-15.5)$ & $651(+37.9)$ & $335(-12.8)$ \\
\hline 2005 & $8,268(+1.3)$ & $668(-11.6)$ & $626(-3.8)$ & $429(+28.1)$ \\
\hline 2006 & $9,040(+9.3)$ & $515(-22.9)$ & $644(+2.9)$ & $442(+3.0)$ \\
\hline 2007 & $9,812(+8.5)$ & $470(-8.7)$ & $604(-6.2)$ & $412(-6.8)$ \\
\hline 2008 & $10,500(+7.0)$ & $627(+33.4)$ & $732(+21.2)$ & $468(+13.6)$ \\
\hline 2009 & $10,988(+4.6)$ & $528(-15.8)$ & $767(+4.8)$ & $458(-2.1)$ \\
\hline 2010 & $11,487(+4.5)$ & $527(-0.2)$ & $773(+0.8)$ & $450(-1.7)$ \\
\hline 2011 & $11,931(+3.9)$ & $415(-21.3)$ & $822(+6.3)$ & $471(+4.7)$ \\
\hline 2012 & $12,719(+6.6)$ & $444(+7.0)$ & $681(-17.2)$ & $497(+5.5)$ \\
\hline 2013 & $13,207(+3.8)$ & $344(-22.5)$ & $655(-3.8)$ & $589(+18.5)$ \\
\hline 2014 & $13,838(+4.8)$ & $339(-1.5)$ & $775(+18.3)$ & $565(-4.1)$ \\
\hline 2015 & $13,994(+1.1)$ & $273(-19.5)$ & $720(-7.1)$ & $561(-0.7)$ \\
\hline 2016 & $14,556(+4.0)$ & $326(+19.4)$ & $1,023(+42.1)$ & $547(-2.5)$ \\
\hline 2017 & $14,502(-0.4)$ & $217(-33.4)$ & $962(-6.0)$ & $537(-1.8)$ \\
\hline 2018 & $14,905(+2.8)$ & $205(-5.5)$ & $1,047(+8.8)$ & $600(+11.7)$ \\
\hline
\end{tabular}

${ }^{a}$ Includes BS Pharmacy, BPharm, and PharmD1 from 1981-2005. Includes only PharmD1 beginning in 2006

${ }^{b}$ PharmD2 refers to the Doctor of Pharmacy degree awarded as a postbaccalaureate degree

degrees conferred in 2017-18. of PharmD two-degree recipients who were foreign, nonpermanent residents of the US was $14.6 \%$, down slightly from $15.2 \%$ in $2016-$ 17 [Table 8].

\section{Graduate Degrees Conferred}

The number of graduate degrees (MS and $\mathrm{PhD}$ ) conferred has shown annual fluctuations over the 50 years data have been consistently gathered and reported
[Table 3]. The number of MS degrees conferred increased to 1,047 in 2017-18 from 962 in 2016-17, an $8.8 \%$ increase. The number of $\mathrm{PhD}$ degrees conferred increased in 2017-18 to 600 from 537 in 2016-17 (11.7\% increase) [Table 5].

The highest percentage of MS degrees awarded in 2017-18 (31.6\%) was in pharmaceutics. The second highest percentage of MS degrees was in social and administrative sciences $(30.1 \%)$; followed by medicinal 
American Journal of Pharmaceutical Education 2019; 83 (6) Article 7658. 
American Journal of Pharmaceutical Education 2019; 83 (6) Article 7658.

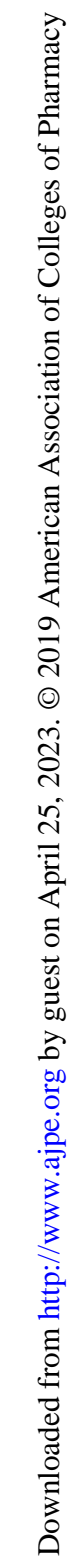

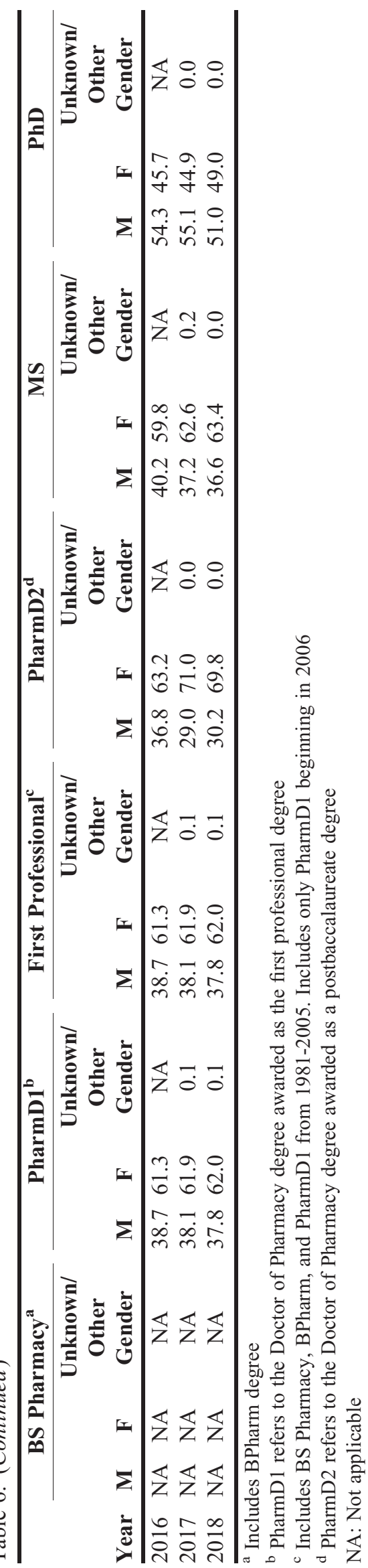

chemistry (15.6\%); pharmacology $(8.5 \%)$; other disciplines $(8.1 \%)$; and pharmacy practice $(6.1 \%)$. The highest number of $\mathrm{PhD}$ degrees awarded in 2017-18 was in the discipline of pharmaceutics (38.5\%). The second highest number was in medicinal chemistry (19.3\%); followed by pharmacology (18.2\%); social and administrative sciences (13.3\%); other disciplines (6.8\%), and pharmacy practice $(3.8 \%)$.

More women than men earned MS degrees (women, 63.4\%; men, 36.6\%; Unknown/Other Gender 0.0\%); however, more men than women earned $\mathrm{PhD}$ degrees (women, 49.0\%; men, 51.0\%) in 2017-18. There have only been two years (2012-13 and 2008-09) since AACP began collecting data that women received more $\mathrm{PhD}$ degrees than men. The percentage of women receiving $\mathrm{PhD}$ degrees has grown substantially from $51.0 \%$ in $2017-18$ from only $18.0 \%$ in $1979-80$ [Table 6].

Underrepresented minorities received $11.1 \%$ of MS degrees in 2017-18 (Black or African American, 5.7\%; Hispanic or Latino, 4.7\%; Native Hawaiian or Other Pacific Islander, 0.2\%; American Indian or Alaska Native, $0.5 \%$ ), a slight decrease from $11.2 \%$ in $2016-17$. Asian Americans received $10.9 \%$ of the MS degrees conferred, down from $13.4 \%$ in 2016-17. The percentage of MS degree recipients who were of two or more races was $1.1 \%$ and the $\%$ of degree recipients who were foreign, nonpermanent residents of the US was $38.9 \%$, up from $30.2 \%$ in 2016-17. [Table 11].

Underrepresented minorities earned $4.8 \%$ of the $\mathrm{PhD}$ degrees awarded in 2017-18 (Black or African American, 3.5\%; Hispanic or Latino, 1.2\%; Native Hawaiian or Other Pacific Islander, $0.0 \%$; American Indian or Alaska Native, $0.2 \%$ ), a decrease from $5.2 \%$ in 201617. Asian Americans earned $7.7 \%$ of the $\mathrm{PhD}$ degrees awarded. The percentage of $\mathrm{PhD}$ degree recipients who were of two or more races was $0.2 \%$ and The percentage of degree recipients that were foreign, nonpermanent residents of the US was $57.2 \%$, up from $57.0 \%$ in 2016-17. [Table 12].

\section{FALL 2018 ENROLLMENTS}

The 2018 Undergraduate and Professional Pharmacy Degree Enrollment Survey and Graduate Degree Enrollment Survey were conducted online in October 2018 , with an announcement and request for participation sent to the survey coordinator at each of the 143 colleges and schools of pharmacy in the US recognized by ACPE. Submission of the data was requested by December 2018. After follow-up correspondence, 143 colleges and schools (100\%) submitted the requested information. 
American Journal of Pharmaceutical Education 2019; 83 (6) Article 7658.

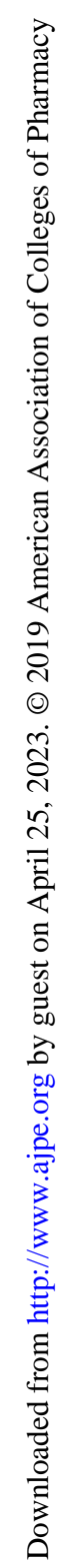

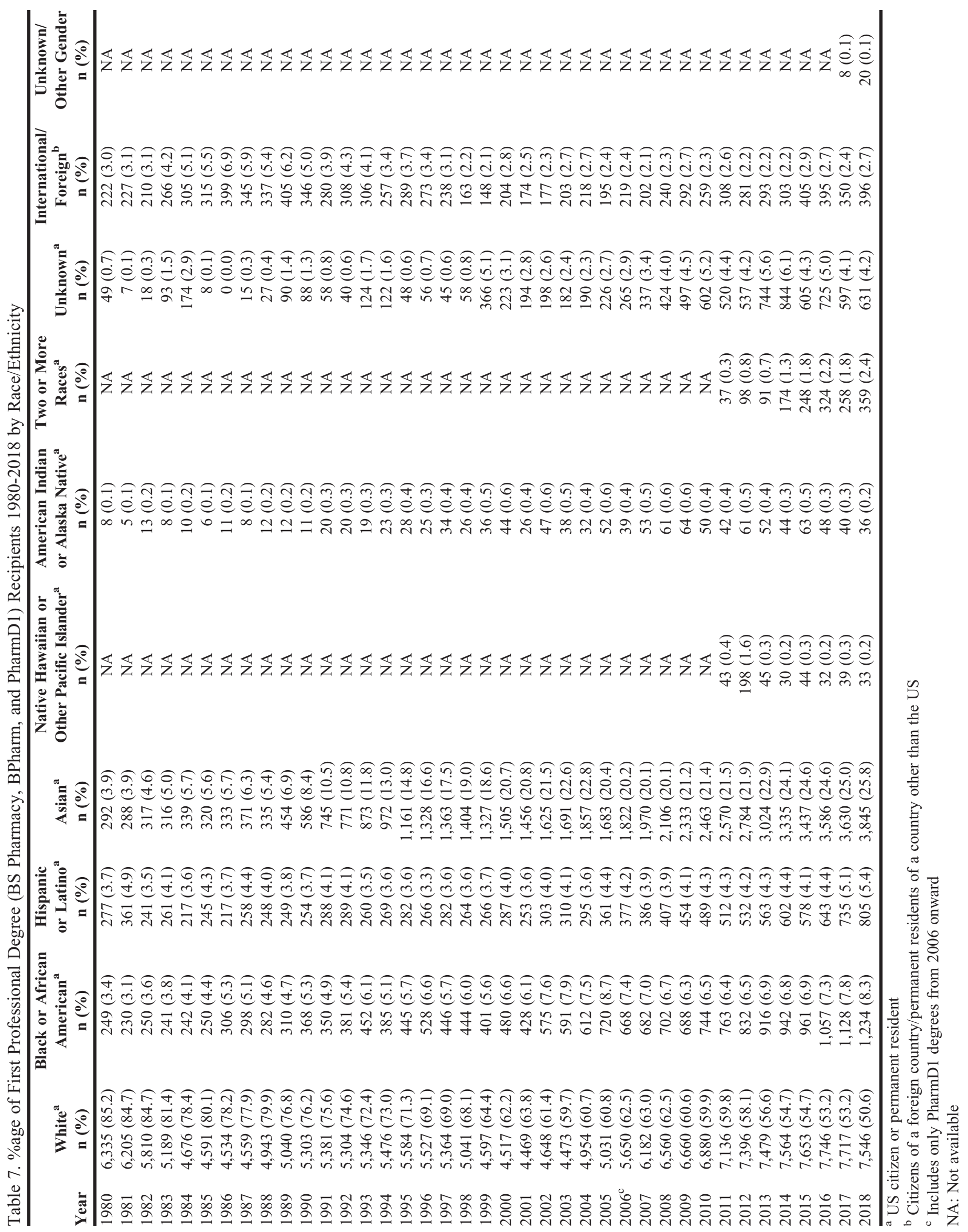


American Journal of Pharmaceutical Education 2019; 83 (6) Article 7658.

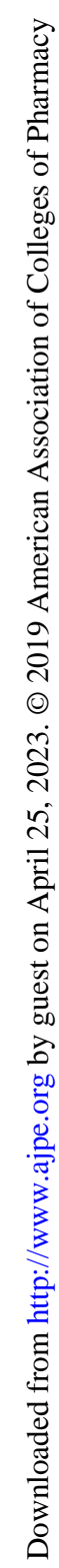

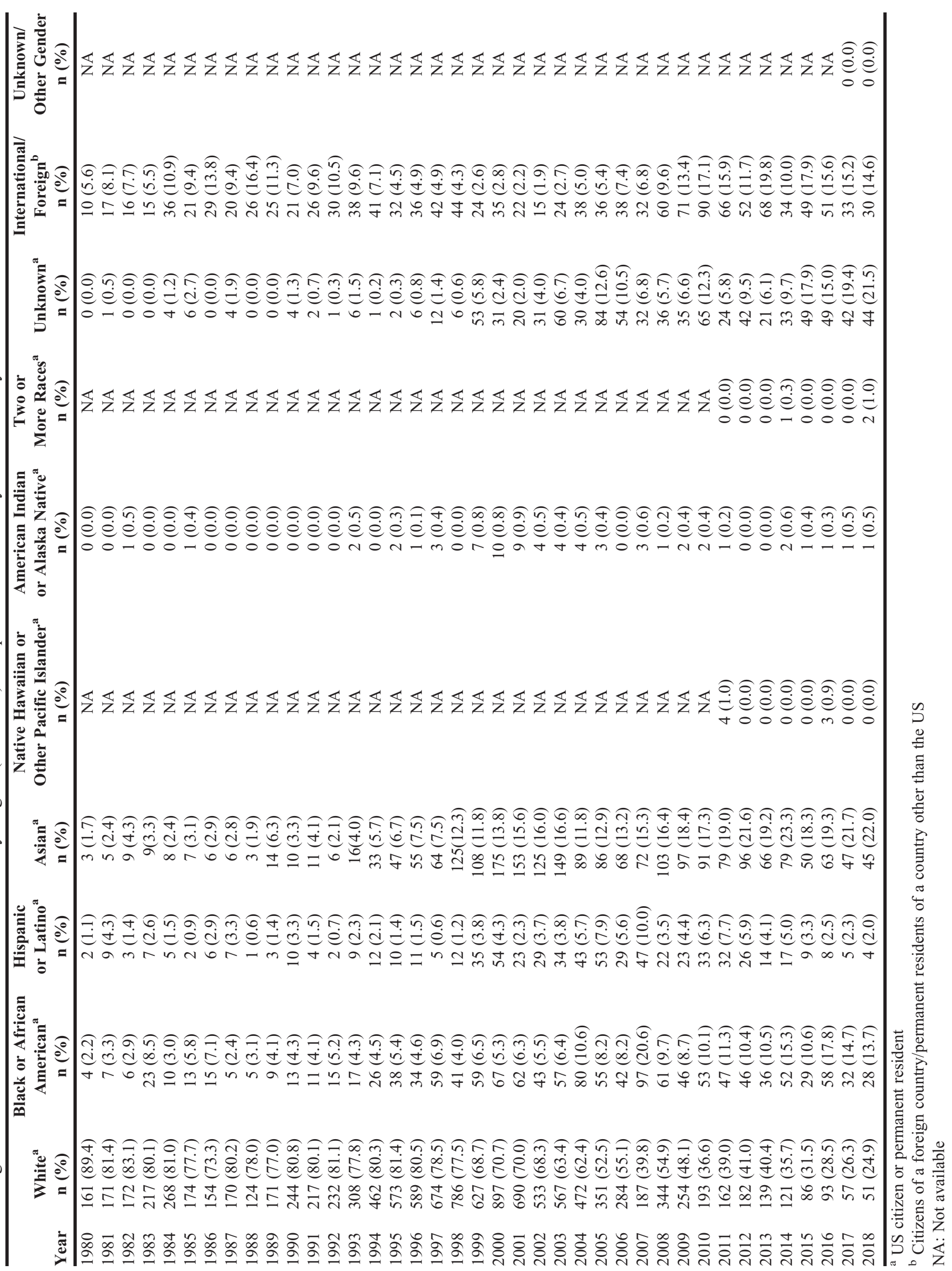




\section{American Journal of Pharmaceutical Education 2019; 83 (6) Article 7658.}

Table 9. Summary of Master of Science and Doctor of Philosophy Degrees Conferred 2017-18 by Gender and Discipline

\begin{tabular}{|c|c|c|c|c|c|c|c|c|c|c|}
\hline \multirow[b]{2}{*}{ Discipline } & \multicolumn{5}{|c|}{ MS Degree } & \multicolumn{5}{|c|}{ PhD Degree } \\
\hline & M & $\mathbf{F}$ & U/O & Total & $\begin{array}{l}\% \text { of MS Degrees } \\
\text { Conferred }\end{array}$ & $\mathbf{M}$ & $\mathbf{F}$ & $\mathrm{U} / \mathbf{O}$ & Total & $\begin{array}{c}\% \text { of PhD Degree } \\
\text { Conferred }\end{array}$ \\
\hline Medicinal chemistry & 49 & 114 & 0 & 163 & 15.6 & 64 & 52 & 0 & 116 & 19.3 \\
\hline Pharmacology & 39 & 50 & 0 & 89 & 8.5 & 50 & 59 & 0 & 109 & 18.2 \\
\hline Social and administrative sciences & 113 & 202 & 0 & 315 & 30.1 & 40 & 40 & 0 & 80 & 13.3 \\
\hline Pharmacy practice & 29 & 35 & 0 & 64 & 6.1 & 8 & 15 & 0 & 23 & 3.8 \\
\hline Pharmaceutics & 124 & 207 & 0 & 331 & 31.6 & 123 & 108 & 0 & 231 & 38.5 \\
\hline Other $^{\mathrm{a}}$ & 29 & 56 & 0 & 85 & 8.1 & 21 & 20 & 0 & 41 & 6.8 \\
\hline Total & 383 & 664 & & 1,047 & & 306 & 294 & & 600 & \\
\hline
\end{tabular}

${ }^{a}$ Includes biophysics/biological \& medical informatics, regulatory science and HCDA, pharmaceutical affairs, pharmacy, pharmacogenomics, public health, hospital pharmacy administration in MS programs and biophysics/biological \& medical informatics, DRSc, pharmaceutical sciences, pharmacogenetics, pharmacy, and ethics/pharmacy/therapeutics in $\mathrm{PhD}$ programs

\section{Professional Degree Programs}

Fall 2018 enrollments in PharmD as the first professional degree programs $(n=62,504)$ represented a $0.9 \%$ decrease from enrollments in fall $2017(\mathrm{n}=$ 63,087 ) [Table 13]. In fall 2018, $63.0 \%$ of the students enrolled in the PharmD as the first professional degree programs were females and $36.9 \%$ were males [Table 14].

White Americans nearly comprised the majority (48.8\%) of students enrolled in the PharmD as the first professional degree programs. Asian Americans accounted for 24.7\%; Black or African Americans, 9.1\%; Hispanic or Latino, 6.5\%; Native Hawaiians/Other Pacific Islanders. $0.2 \%$; American Indians/Alaska Natives, $0.4 \%$; and international/foreign students, 3.1\%. Students where race/ethnicity was unknown accounted for $3.9 \%$ of enrollees and students that identified as two or more races accounted for $3.2 \%$ of all first professional degree enrollments. Students whose race/ethnicity and gender were unknown accounted for $0.1 \%$ of enrollments. Enrollments of underrepresented minorities (Black or African American, Hispanic or Latino, Native Hawaiian or Other Pacific Islander, American Indian or Alaska Native) as a\%age of total enrollments in the PharmD as a first professional degree programs increased to $16.2 \%$ in fall 2018 from $15.3 \%$ in fall 2017 [Table 15].

Nine colleges and schools reported 764 students who already held a baccalaureate in pharmacy enrolled in Doctor of Pharmacy degree programs (PharmD). This was a decrease of $1.2 \%$ from fall 2017 . Underrepresented minorities accounted for $22.8 \%$ of these students (Black or African American, 20.4\%; Hispanic, 2.0\%; Native Hawaiians/Other Pacific Islander, 0.3\%; American Indians/ Alaska Native, 0.1\%). White Americans comprised 34.4\%; Asian Americans, 17.5\%; students of two or more races,
$1.0 \%$; unknown, $12.3 \%$; and international/foreign students, $11.5 \%$; and students of unknown race/ethnicity and gender, $0.4 \%$.

\section{Graduate Degree Programs}

In fall 2018, the discipline of pharmaceutics had the highest percentage of full-time enrollees at both the MS and $\mathrm{PhD}$ levels (47.2\% and $40.2 \%$, respectively). At the master's level, $18.7 \%$ of the students were in enrolled in social and administrative sciences programs; $11.3 \%$ in pharmacology programs; $8.7 \%$ in other disciplines; $7.3 \%$ in pharmacy practice programs; and $6.8 \%$ in medicinal chemistry programs. At the doctoral level, 23.4\% of the students were enrolled in medicinal chemistry programs; $16.0 \%$ in pharmacology programs; $12.0 \%$ in social and administrative science programs; $4.6 \%$ in other disciplines; and $3.9 \%$ in pharmacy practice [Table 16].

In fall 2018, more females than males were enrolled full-time in both $\mathrm{MS}$ and $\mathrm{PhD}$ degree programs. In MS programs females accounted for $62.8 \%$ of enrollments and males, $37.2 \%$. Women accounted for $51.0 \%$ of $\mathrm{PhD}$ full-time enrollments, an increase from $48.4 \%$ in fall 2017.

Of the 1,319 students enrolled full-time in MS degree programs in fall 2018, approximately half (49.9\%) were foreign students. White Americans comprised 24.3\% of enrollees and Asian Americans accounted for 10.2\%. Underrepresented minorities accounted for $10.5 \%$ of MS enrollees (Black or African American, 4.3\%; Hispanic or Latino, 5.5\%; Native Hawaiian or Other Pacific Islander, 0.2\%; American Indian or Alaska Native, 0.5\%). Americans of two or more races made up $1.7 \%$ of enrollees and $3.4 \%$ of all full-time MS degree enrollees were reported as race/ethnicity unknown.

Of the 3,205 students enrolled full-time in $\mathrm{PhD}$ degree programs in fall 2018, foreign students were also the 


\section{American Journal of Pharmaceutical Education 2019; 83 (6) Article 7658.}

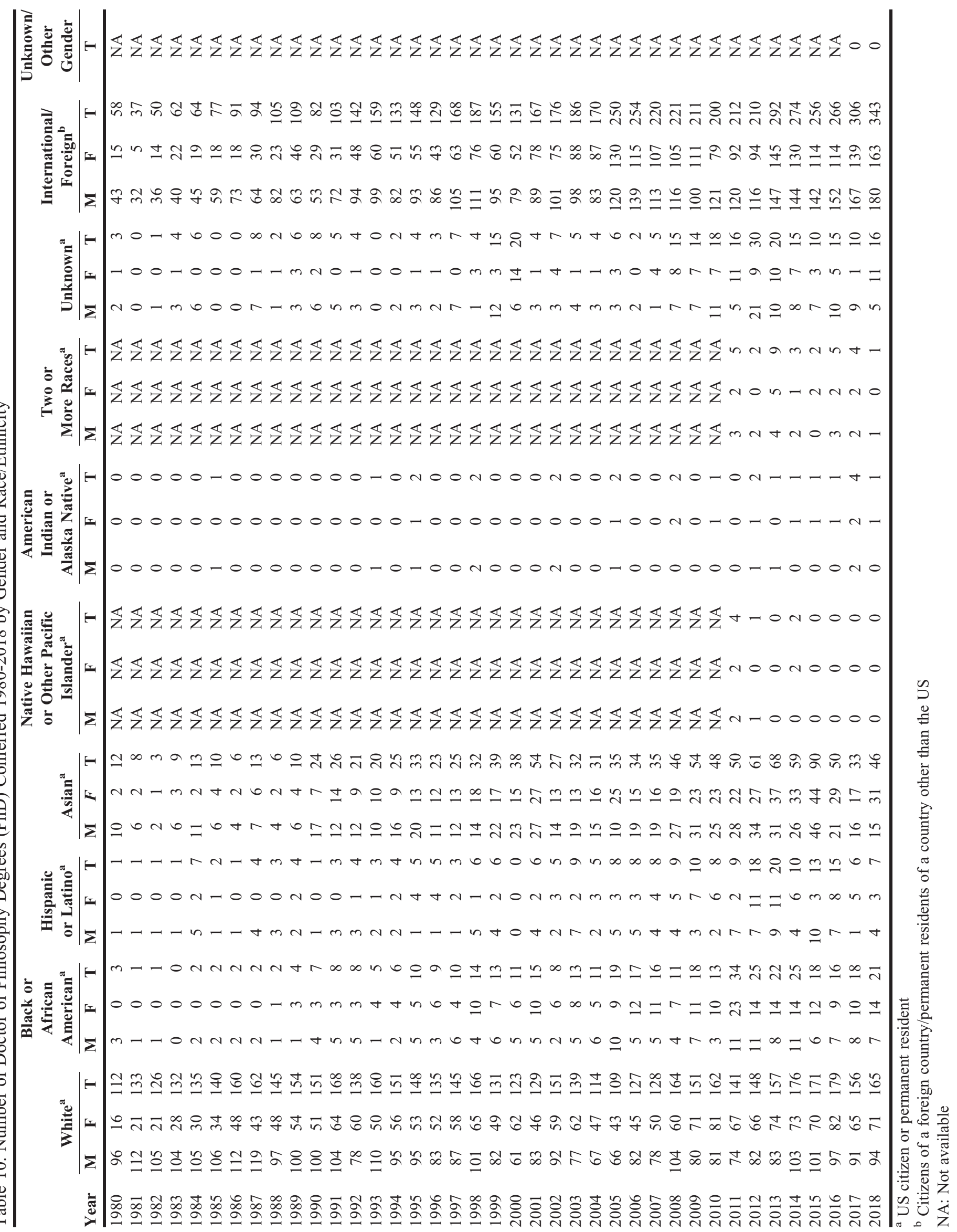


American Journal of Pharmaceutical Education 2019; 83 (6) Article 7658.

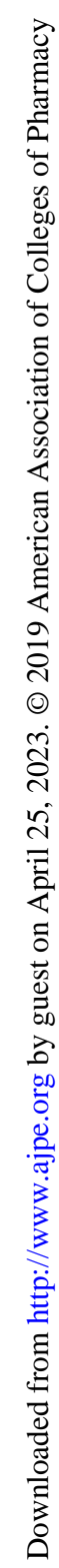

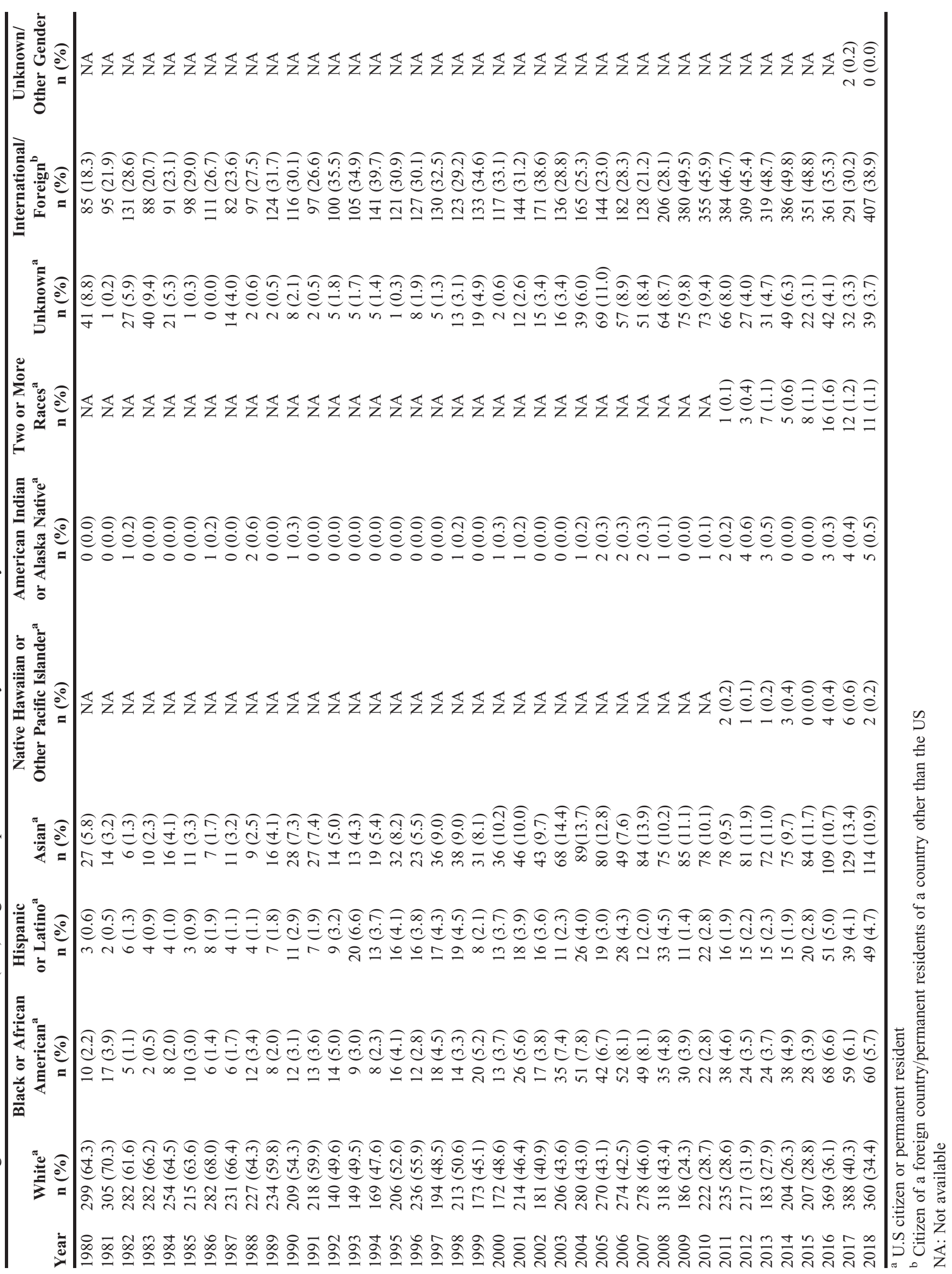


American Journal of Pharmaceutical Education 2019; 83 (6) Article 7658.

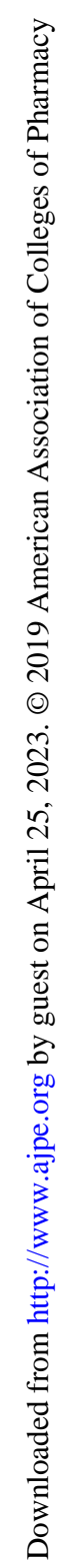

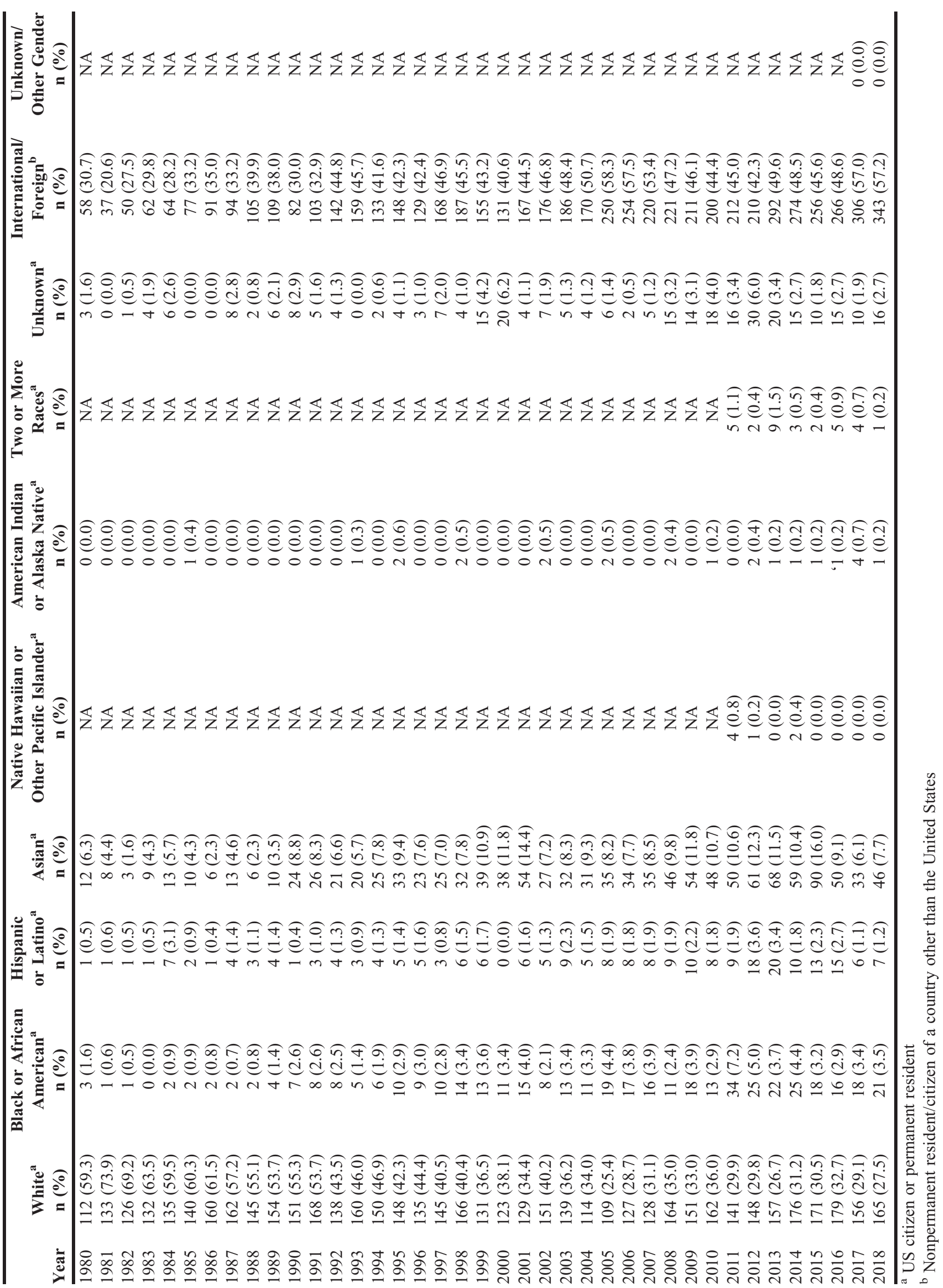




\section{American Journal of Pharmaceutical Education 2019; 83 (6) Article 7658.}

Table 13. Summary of Enrollments in First Professional Degree Programs 1980-2018

\begin{tabular}{|c|c|c|c|}
\hline Year & $\frac{\text { First Professional Year Classes, }}{\text { No. }(\% \text { Change })}$ & $\frac{\text { All Professional Years, }}{\text { No. }(\% \text { Change })_{-}}$ & $\frac{\text { Total Enrollment, }}{\text { No. (\% Change) }}$ \\
\hline 1980 & 7,377 & 22,093 & 26,617 \\
\hline 1982 & $6,609(-4.6)$ & $19,350(-5.5)$ & $23,410(-5.1)$ \\
\hline 1983 & $6,635(0.4)$ & $18,831(-2.7)$ & $23,091(-1.4)$ \\
\hline 1984 & $6,986(5.3)$ & $18,646(-1.0)$ & $23,312(1.0)$ \\
\hline 1986 & $7,554(6.5)$ & $20,073(5.1)$ & $25,643(3.3)$ \\
\hline 1987 & $7,751(2.6)$ & $21,424(6.7)$ & $27,292(6.4)$ \\
\hline 1988 & $7,990(3.1)$ & $22,447(4.8)$ & $28,891(5.9)$ \\
\hline 1989 & $8,033(0.5)$ & $23,013(2.5)$ & $29,560(2.3)$ \\
\hline 1990 & 8,267 (2.9) & $23,238(1.0)$ & $29,797(0.8)$ \\
\hline 1995 & $8,740(-4.6)$ & $28,060(1.4)$ & $33,415(0.2)$ \\
\hline 1996 & $9,561(9.4)$ & $28,027(-0.1)$ & $33,059(-1.1)$ \\
\hline 1997 & $8,571(-10.4)$ & $28,345(1.1)$ & $32,529(-1.6)$ \\
\hline 1998 & $8,346(-2.6)$ & $28,568(0.8)$ & $33,090(1.7)$ \\
\hline 1999 & $8,123(-2.7)$ & $29,586(3.6)$ & $32,537(-1.7)$ \\
\hline 2000 & $8,382(3.2)$ & $30,301(2.4)$ & $34,481(6.0)$ \\
\hline 2001 & $8,922(6.4)$ & $31,769(4.8)$ & $35,885(4.1)$ \\
\hline 2002 & $9,128(2.3)$ & $33,437(5.3)$ & $38,902(8.4)$ \\
\hline 2003 & $9,909(8.6)$ & $36,454(9.0)$ & $41,762(10.7)$ \\
\hline 2004 & $10,437(5.3)$ & $38,544(5.7)$ & $43,908\left(-^{c}\right)$ \\
\hline 2012 & $14,011(4.1)$ & $56,489(4.5)$ & $61,275(4.0)$ \\
\hline 2013 & $14,008(0.0)$ & $58,121(2.9)$ & $62,743(2.4)$ \\
\hline 2014 & 14,276 (1.9) & $59,370(2.1)$ & 63,927 (1.9) \\
\hline 2015 & $14,190(-0.6)$ & $59,720(0.6)$ & $63,460(-0.7)$ \\
\hline 2016 & $13,975(-1.5)$ & $59,978(0.4)$ & $63,464(0.0)$ \\
\hline 2017 & $13,881(-0.7)$ & $59,474(-0.8)$ & $63,087(-0.6)$ \\
\hline 2018 & $13,546(-2.4)$ & $59,208(-0.4)$ & $62,504(-0.9)$ \\
\hline
\end{tabular}

${ }^{a}$ Includes second from last year for baccalaureate and third from last year for PharmD1 and does not include first year enrollees in accelerated programs from 1980-2005. Includes third from last year PharmD1 beginning in 2006

${ }^{b}$ Includes the final three years only of all first professional degree programs for 1980-1991; includes all professional years for 1992-present (3 years for baccalaureate and 4 years for PharmD)

${ }^{\mathrm{c}}$ Not able to calculate $\%$ change due to change in how data are reported by select institutions 
American Journal of Pharmaceutical Education 2019; 83 (6) Article 7658.

Table 14. Summary of Enrollments in First Professional Degree Programs by Gender 1980-2018

\begin{tabular}{|c|c|c|c|c|c|c|c|c|}
\hline \multirow[b]{2}{*}{ Year } & \multicolumn{2}{|c|}{ Male } & \multicolumn{2}{|c|}{ Female } & \multicolumn{2}{|c|}{$\begin{array}{c}\text { Unknown/Other Gender } \\
\end{array}$} & \multicolumn{2}{|c|}{ Total Enrollment } \\
\hline & No. (\%) & $\begin{array}{l}\text { \% Change from } \\
\text { Previous Year }\end{array}$ & No. (\%) & $\begin{array}{l}\text { \% Change from } \\
\text { Previous Year }\end{array}$ & No. & $\begin{array}{l}\text { \% Change from } \\
\text { Previous Year }\end{array}$ & No. & $\begin{array}{l}\text { \% Change from } \\
\text { Previous Year }\end{array}$ \\
\hline 1981 & $12,413(50.3)$ & -11.3 & $12,245(49.7)$ & -3.0 & NA & NA & 24,658 & -7.4 \\
\hline 1982 & $11,271(48.1)$ & -9.2 & $12,139(51.9)$ & -0.9 & NA & NA & 23,410 & -5.1 \\
\hline 1983 & $10,984(47.6)$ & -2.5 & $12,107(52.4)$ & -0.3 & NA & NA & 23,091 & -1.4 \\
\hline 1985 & $10,685(43.0)$ & 3.3 & $14,135(57.0)$ & 9.0 & NA & NA & 24,820 & 6.5 \\
\hline 1986 & $10,628(41.4)$ & -0.5 & $15,015(58.6)$ & 6.2 & NA & NA & 25,643 & 3.3 \\
\hline 1987 & $10,907(40.0)$ & 2.6 & $16,385(60.0)$ & 9.1 & NA & NA & 27,292 & 6.4 \\
\hline 1988 & $11,382(39.4)$ & 4.4 & $17,509(60.6)$ & 6.9 & NA & NA & 28,891 & 5.9 \\
\hline 1989 & $11,350(38.4)$ & -0.3 & $18,210(61.6)$ & 4.0 & NA & NA & 29,560 & 2.3 \\
\hline 1994 & $12,243(36.7)$ & 1.0 & $21,110(63.3)$ & 1.4 & NA & NA & 33,353 & 1.3 \\
\hline 1995 & $12,221(36.6)$ & -0.2 & $21,194(63.4)$ & 0.4 & NA & NA & 33,415 & 0.2 \\
\hline 1996 & $11,966(36.2)$ & -2.1 & $21,093(63.8)$ & -0.5 & NA & NA & 33,059 & -1.1 \\
\hline 1997 & $11,652(35.8)$ & -2.6 & 20,877 (64.2) & -1.0 & NA & NA & 32,529 & -1.6 \\
\hline 1998 & $11,777(35.6)$ & 1.1 & $21,313(64.4)$ & 2.1 & NA & NA & 33,090 & 1.7 \\
\hline 1999 & $11,411(35.1)$ & -3.1 & $21,126(64.9)$ & -0.9 & NA & NA & 32,537 & -1.7 \\
\hline 2000 & $11,763(34.1)$ & 3.1 & 22,718 (65.9) & 7.5 & NA & NA & 34,481 & 6.0 \\
\hline 2001 & $12,253(34.1)$ & 4.2 & $23,632(65.9)$ & 4.0 & NA & NA & 35,885 & 4.1 \\
\hline 2002 & $12,815(33.0)$ & 4.6 & $26,087(67.0)$ & 9.1 & NA & NA & 38902 & 8.4 \\
\hline 2003 & $13,874(33.2)$ & 11.3 & $27,888(66.8)$ & 10.3 & NA & NA & 41,762 & 10.7 \\
\hline 2011 & $23,100(39.2)$ & 4.1 & $35,815(60.8)$ & 3.4 & NA & NA & 58,915 & 3.6 \\
\hline 2012 & $23,900(39.0)$ & 3.5 & $37,375(61.0)$ & 4.4 & NA & NA & 61,275 & 4.0 \\
\hline 2013 & $24,326(38.8)$ & 1.8 & 38,417 (61.2) & 2.8 & NA & NA & 62,743 & 2.4 \\
\hline 2014 & $24,655(38.6)$ & 1.4 & $39,272(61.4)$ & 2.2 & NA & NA & 63,927 & 1.9 \\
\hline 2015 & $24,476(38.6)$ & -0.7 & $38,984(61.4)$ & -0.7 & NA & NA & 63,460 & -0.7 \\
\hline 2016 & $24,174(38.1)$ & -1.2 & 39,278 (61.9) & 0.8 & NA & NA & 63,464 & 0.0 \\
\hline 2017 & $23,608(37.4)$ & -2.3 & $39,435(62.5)$ & 0.4 & $44(0.1)$ & NA & 63,087 & -0.6 \\
\hline 2018 & $23,084(36.9)$ & -2.2 & $39,349(63.0)$ & -0.2 & $71(0.1)$ & NA & 62,504 & -0.9 \\
\hline
\end{tabular}

${ }^{a}$ Not able to calculate $\%$ change due to change in how data is reported by select institutions

${ }^{\mathrm{b}}$ Includes only PharmD1 degrees beginning in 2006

NA: Not available 
American Journal of Pharmaceutical Education 2019; 83 (6) Article 7658.

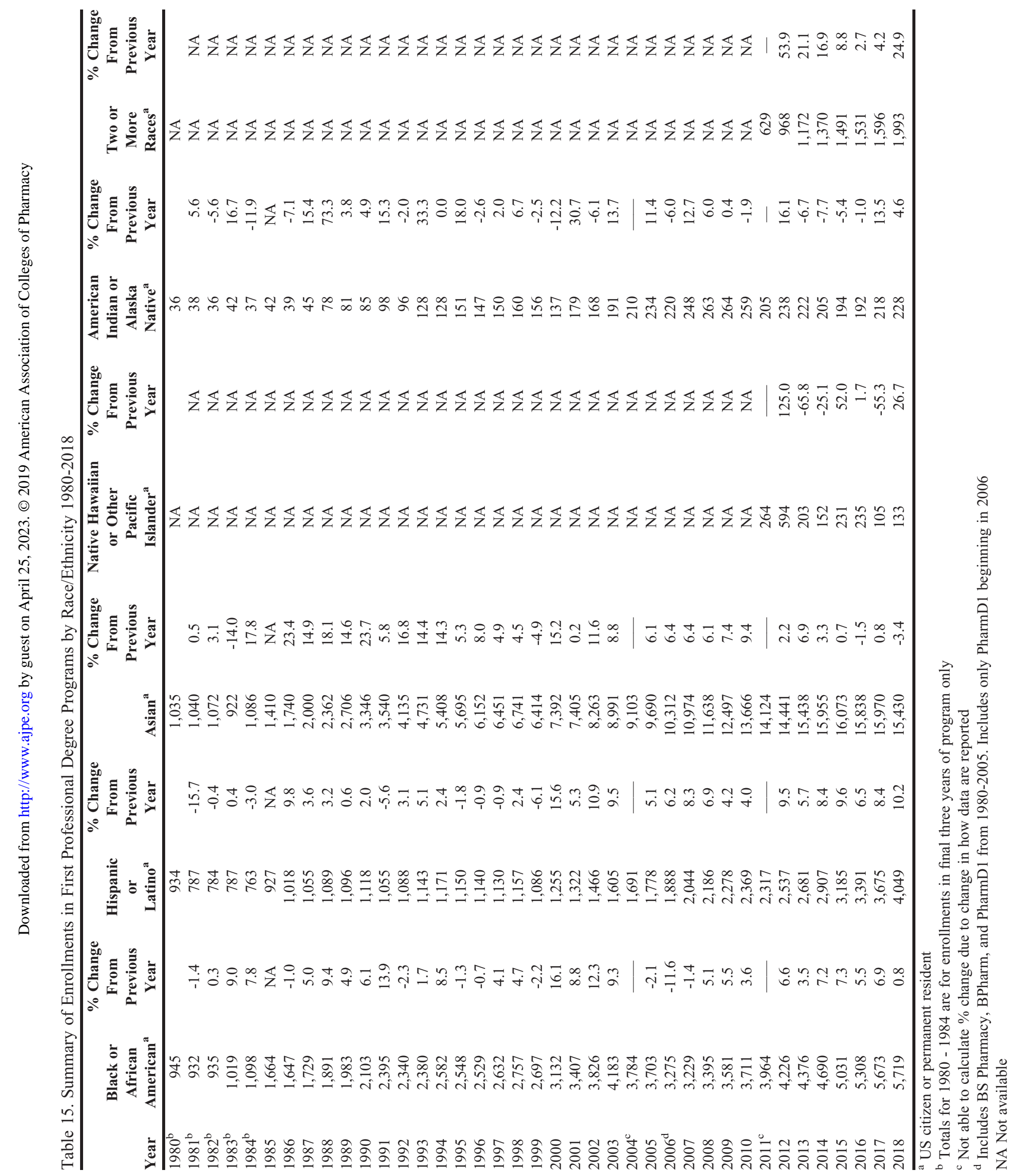


American Journal of Pharmaceutical Education 2019; 83 (6) Article 7658.

Table 16. Summary of Master of Science (MS) and Doctor of Philosophy (PhD) Fall 2018 Full-Time Enrollments by Gender and Discipline

\begin{tabular}{|c|c|c|c|c|c|c|c|c|c|c|}
\hline \multirow[b]{2}{*}{ Discipline } & \multicolumn{5}{|c|}{ MS Degree } & \multicolumn{5}{|c|}{ PhD Degree } \\
\hline & M & $\mathbf{F}$ & $\mathbf{U} / \mathbf{O}$ & $\mathbf{T}$ & $\begin{array}{l}\% \text { of MS Program } \\
\text { Enrollments }\end{array}$ & M & $\mathbf{F}$ & $\mathrm{U} / \mathbf{O}$ & $\mathbf{T}$ & $\begin{array}{c}\text { \% of PhD Program } \\
\text { Enrollments }\end{array}$ \\
\hline Medicinal Chemistry & 32 & 58 & 0 & 90 & 6.8 & 402 & 347 & 0 & 749 & 23.4 \\
\hline Pharmacology & 54 & 95 & 0 & 149 & 11.3 & 220 & 292 & 0 & 512 & 16.0 \\
\hline $\begin{array}{l}\text { Social and Administrative } \\
\text { Sciences }\end{array}$ & 93 & 154 & 0 & 247 & 18.7 & 160 & 224 & 0 & 384 & 12.0 \\
\hline Pharmacy Practice & 29 & 67 & 0 & 96 & 7.3 & 63 & 62 & 0 & 125 & 3.9 \\
\hline Pharmaceutics & 238 & 384 & 0 & 622 & 47.2 & 648 & 640 & 0 & 1,288 & 40.2 \\
\hline Other $^{\mathrm{a}}$ & 45 & 70 & 0 & 115 & 8.7 & 77 & 70 & 0 & 147 & 4.6 \\
\hline Total & 491 & 828 & 4 & 1,319 & & 1,570 & 1,635 & 0 & 3,205 & \\
\hline
\end{tabular}

${ }^{a}$ Includes genetic counseling/genomic data analytics, pharmaceutical affairs, pharmaceutical and biomedical science, undeclared, pharmacogenomics, biomolecular sciences, public health, and health-system pharmacy administration for MS programs and biophysics/biology \& med informatics, pharmacogenetics, pharmaceutical and biomedical sciences, undeclared, biomolecular sciences, pharmacotherapeutics, and translational science for $\mathrm{PhD}$ programs

largest group, accounting for $49.9 \%$ of the enrollees. White Americans were the next largest group at $31.1 \%$ of full-time enrollments, followed by Asian Americans $8.2 \%$. Underrepresented minorities accounted for $8.3 \%$ of $\mathrm{PhD}$ enrollees (Black or African American, 4.5\%; Hispanic or Latino, 3.6\%; Native Hawaiian or Other Pacific Islander, $0.0 \%$; American Indian or Alaska Native, $0.2 \%$ ). Americans of two or more races accounted for $1.2 \%, 1.3 \%$ of all full-time $\mathrm{PhD}$ degree enrollees had unknown race/ ethnicity. For graduate students, whose source of degree was reported, over $41 \%$ (41.1) of full-time and part-time students in $\mathrm{PhD}$ programs held a professional pharmacy degree, $11.8 \%$ of $\mathrm{PhD}$ students held a professional pharmacy degree from a US college or school of pharmacy and $29.3 \%$ held a pharmacy degree conferred by a non-US institution [Table 17].

Table 17. Fall 2018 Enrollments in PhD Programs by Type of Enrollment (Full-Time, Part-Time), Discipline, and Source of Previous Degree Earned ${ }^{\mathrm{a}}$

\begin{tabular}{|c|c|c|c|c|c|c|c|c|}
\hline & \multicolumn{2}{|c|}{ US School } & \multicolumn{2}{|c|}{ Canadian School } & \multicolumn{2}{|c|}{ Foreign School } & \multicolumn{2}{|c|}{ All Schools } \\
\hline & Pharm & Non-Pharm & Pharm & Non-Pharm & Pharm & Non-Pharm & Pharm & Non-Pharm \\
\hline \multicolumn{9}{|l|}{ Full-Time } \\
\hline Medicinal Chemistry & 60 & 364 & 1 & 3 & 110 & 118 & 171 & 485 \\
\hline Pharmacology & 34 & 205 & 1 & 0 & 149 & 83 & 184 & 288 \\
\hline Social and Admin. Sciences & 65 & 109 & 0 & 0 & 122 & 68 & 187 & 177 \\
\hline Pharmacy Practice & 27 & 43 & 0 & 0 & 38 & 19 & 65 & 62 \\
\hline Pharmaceutics & 130 & 408 & 0 & 1 & 390 & 238 & 520 & 647 \\
\hline Other & 4 & 12 & 0 & 0 & 17 & 5 & 21 & 17 \\
\hline Total full-time & 320 & 1,141 & 2 & 4 & 826 & 531 & 1,148 & 1,676 \\
\hline \multicolumn{9}{|l|}{ Part-Time } \\
\hline Medicinal Chemistry & 2 & 1 & 0 & 0 & 4 & 3 & 6 & 4 \\
\hline Pharmacology & 15 & 9 & 0 & 0 & 5 & 0 & 20 & 9 \\
\hline Social and Admin. Sciences & 2 & 2 & 0 & 0 & 2 & 2 & 4 & 4 \\
\hline Pharmacy Practice & 1 & 1 & 0 & 0 & 6 & 1 & 7 & 2 \\
\hline Pharmaceutics & 6 & 31 & 0 & 1 & 18 & 6 & 24 & 38 \\
\hline Other & 0 & 1 & 0 & 0 & 1 & 0 & 1 & 1 \\
\hline Total part-time & 26 & 45 & 0 & 1 & 36 & 12 & 62 & 58 \\
\hline
\end{tabular}

${ }^{a}$ Includes only those students for whom source of degree was reported 
American Journal of Pharmaceutical Education 2019; 83 (6) Article 7658.

\section{ACKNOWLEDGMENTS}

The American Association of Colleges of Pharmacy wishes to express its appreciation to the deans of its member institutions and members of their faculty and staff who devoted their valuable time to complete the surveys that led to this report.

This report is an excerpt from the Profile of Pharmacy Students - Fall 2018, published by the American Association of Colleges of Pharmacy (2019). 